\title{
Transient Receptor Potential Cation Channel Subfamily M Member 6
}

National Cancer Institute

\section{Source}

National Cancer Institute. Transient Receptor Potential Cation Channel Subfamily M

Member 6. NCl Thesaurus. Code C147084.

Transient receptor potential cation channel subfamily M member 6 (2022 aa, 232 kDa)

is encoded by the human TRPM6 gene. This protein plays a role in serine/threonine phosphorylation and magnesium absorption in the gut and kidney. 